\title{
Calibration of Digital Thermometer using Sensor and Indicator Method
}

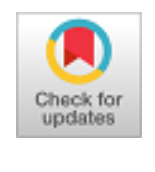

\author{
Fitria Hidayanti, Ukhti Fathimah Ramadhani
}

\begin{abstract}
A Calibration has been done for digital thermometer using a sensor and indicator method. The unit under test manufactured by Fluke with 54-II type and serial number 13160058, meanwhile, the standards that used are PT100 sensor from Omega and an indicator from Additel. The calibration result from 12 setpoints shows the average correction value as $0.61{ }^{\circ} \mathrm{C}$ with uncertainty as $0.32{ }^{\circ} \mathrm{C}$ and $\mathrm{K}$ factor as 2.0 at $95 \%$ confidence level.
\end{abstract}

Keywords: calibration, correction, digital thermometer, standard, uncertanity

\section{INTRODUCTION}

Calibration is an activity to determine the actual value of the appointment value of measuring instruments and measuring materials by comparing against measuring standards that can be traced to national and international standards [1].

In temperature calibration [2], some terms need to be known, including:

\section{A. Standard}

A calibration standard [3] is a standard unit for the length, weight, time, temperature, and quantity of electricity that is set so that researchers around the world can compare their experimental results on a consistent basis.

\section{B. Measurement System}

The measurement system [4] consists of three stages. Those are

1. The detector-transducer stage, which detects physical quantities that carry out mechanical or electrical transformations to convert signals into more useful transform a physical effect into another physical effect. However, in many cases, the physics variable is transformed into an electrical signal because in this form, the signal is easily measured.

2. An intermediate stage, which changes the direct signal by amplification, filtering or other means, to obtain the desired output.

3. The final stage that shows records and controls the measured variable.

Revised Manuscript Received on May 15, 2020.

* Correspondence Author

Fitria Hidayanti*, Engineering Physics Department, Universitas Nasional, Jakarta, Indonesia. Email: fitriahidayanti@gmail.com

(C) The Authors. Published by Blue Eyes Intelligence Engineering and Sciences Publication (BEIESP). This is an open access article under the CC BY-NC-ND license (http://creativecommons.org/licenses/by-nc-nd/4.0/) forms. In general, the transducer is a device that can

\section{Temperature}

Temperature is an intuitive concept that states whether an object is "hot" or "cold" for most people. In the translation of the second principle of thermodynamics, the temperature is associated with heat (heat), because it was known that heat flows only from high temperature to low temperature when there are no other effects. Due to pressure, volume, electrical resistivity, expansion coefficient, etc., all depend on temperature through fundamental molecular structures, the properties change according to temperature, and changes can be used to measure temperature, so the concept of temperature is important in all branches of science physical; therefore the experimental engineers have to master the methods used for temperature measurement.

D. Temperature Scale

Two temperature scales [5] that are widely used are the Fahrenheit scale and the Celsius scale. Both of these scales are based on determining the amount of increase between the freezing point and boiling point of water at standard atmospheric pressure. The Celsius scale has 100 units between these two points, while the Fahrenheit scale has 180 units. The absolute Celsius scale is called the Kelvin scale, while the absolute Fahrenheit scale is called the Rankine scale. The two absolute scales are defined in such a way that they are closely related to the thermodynamic temperature scale. The zero points on both absolute scales indicate the same physical state, and the ratio of two values is always the same on both absolute scales.

$$
\left(\frac{T 2}{T 1}\right)_{\text {Rankine }}=\left(\frac{T 2}{T 1}\right)_{\text {Nelvin }}
$$

The boiling point of water at $1 \mathrm{~atm}$ is arbitrarily considered $100^{0}$ on the Celsius scale and $212^{0}$ on the Fahrenheit scale. The relationship between the two scales was shown in the following Fig. 1.

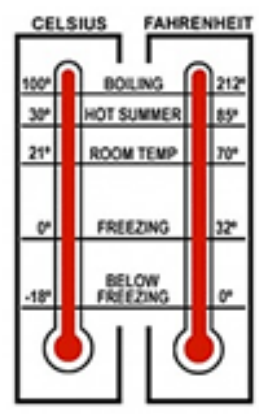

Fig. 1.Relation of Celsius and Fahrenheit Scale [5]

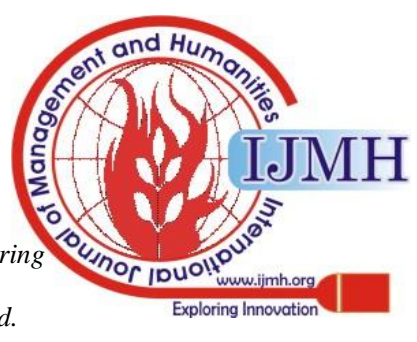




\section{Calibration of Digital Thermometer using Sensor and Indicator Method}

Thus, it is clear that the relation below applies.

${ }^{\circ} \mathrm{F}=32,0+\frac{9}{5} \mathrm{C} C$
${ }^{\circ} \mathrm{C}=\frac{9}{5} K$

\section{E. Thermoelectric Effect}

The most common electrical method for temperature measurement uses thermocouples (thermocouples). If there are two different types of metals, put together, as shown in Fig. 2.

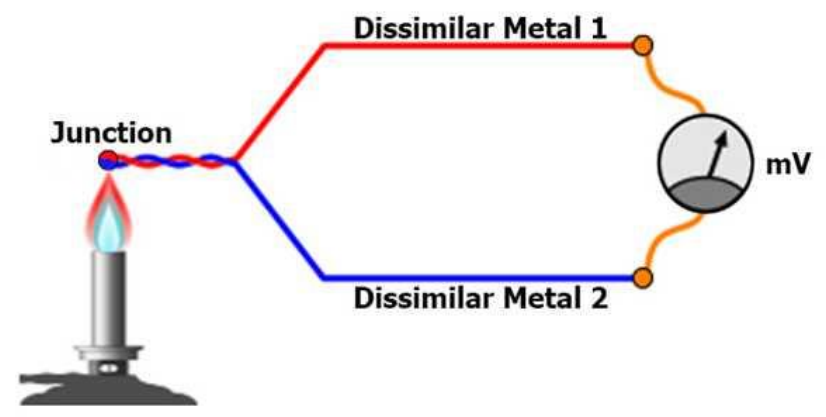

Fig. 2. A simple structure of thermocouples [6]

Then there will be an electric voltage (electromotive force) between two points A and B, which is mainly a function of the junction temperature. This phenomenon is called the Seebeck effect. If the two materials are connected to an external circuit in such a way that current flows, the voltage of electric motion can change slightly due to a phenomenon called the Peltier effect [7-9]. Furthermore, if there is a temperature gradient in one or both materials, the connection will change a little more. This is called the Thomson effect. So, there are three types of electromotive force in the thermoelectric circuit: Seebeck emf, which is caused by unequal metals; emf Peltier caused by the current flowing in the circuit; and Thomson emf, which is caused by the temperature gradient in the material.

Among the three kinds of electric motion voltage contained in the thermoelectric circuit, the most needing attention is the Seebeck emf which produces the Seebeck effect because it depends on the connection temperature. If the voltage generated at the junction of two dissimilar metals is carefully measured as a function of temperature, the connection can be used to measure temperature.

\section{MATERIALS AND METHOD}

The calibration method used in digital thermometer calibration is the sensor plus indicator method, which refers to the JIS Z 8710 standard of 1993 [10], The digital thermometer calibration flow chart with the sensor plus indicator method is as Fig. 3 da Fg. 4.

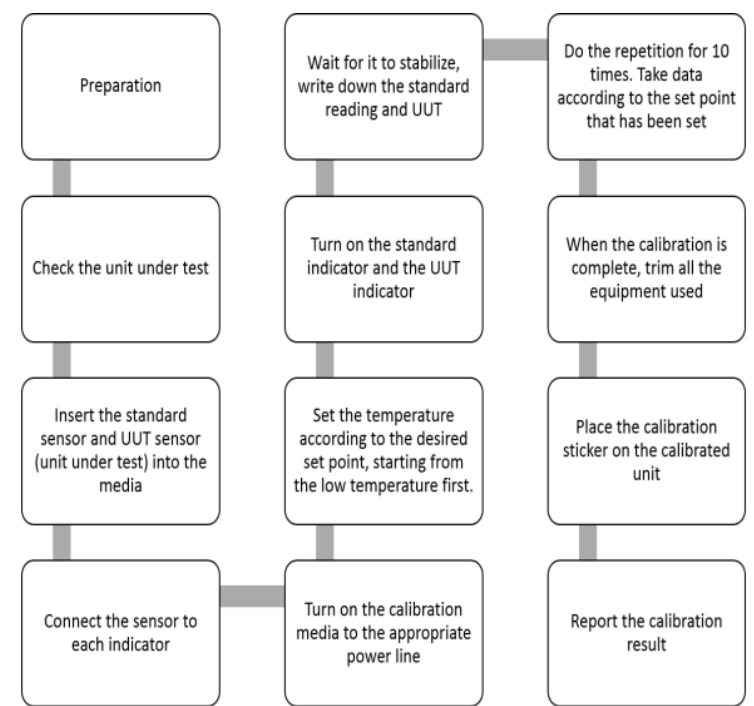

Fig. 3.A digital thermometer calibration flow chart

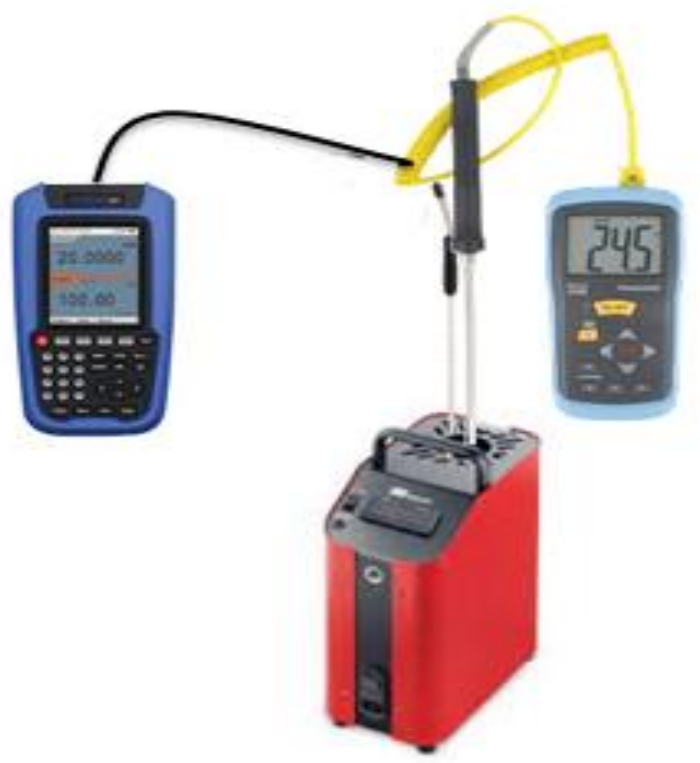

Fig. 4.Calibration Circuit Diagram

\section{RESULTS AND DISCUSSION}

A calibration has been carried out on the digital thermometer with the Fluke brand, type 54-II and serial number 1316058. This thermometer was used as a temperature measuring device with a range $0-160{ }^{\circ} \mathrm{C}$. in this research, calibration points was set in the range into 12 points, namely $0{ }^{0} \mathrm{C}, 10{ }^{\circ} \mathrm{C}, 15^{0} \mathrm{C}, 20{ }^{\circ} \mathrm{C}, 25{ }^{\circ} \mathrm{C}, 30{ }^{\circ} \mathrm{C}, 40{ }^{\circ} \mathrm{C}$, $50{ }^{\circ} \mathrm{C}, 70{ }^{\circ} \mathrm{C}, 100{ }^{0} \mathrm{C}, 120{ }^{\circ} \mathrm{C}$ and $160{ }^{\circ} \mathrm{C}$ as shown in Table 1 - Table 6.

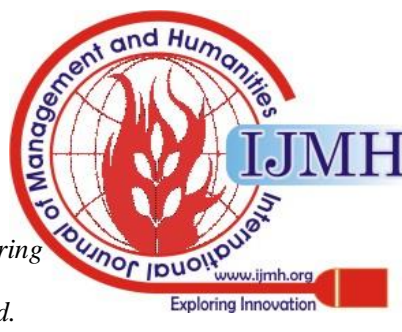


Table 1. Calibration Result of Digital Thermometer for set point $0^{\circ} \mathrm{C}$ and $10{ }^{\circ} \mathrm{C}$

\begin{tabular}{|c|c|c|c|}
\hline Set Point & $0.0{ }^{\circ} \mathrm{C}$ & Set Point : & $10.0^{\circ} \mathrm{C}$ \\
\hline $\begin{array}{l}\text { Standard } \\
\left({ }^{\circ} \mathrm{C}\right) \\
\end{array}$ & Unit Under Test $\left({ }^{\circ} \mathrm{C}\right)$ & $\begin{array}{l}\text { Standard } \\
\left({ }^{\circ} \mathrm{C}\right) \\
\end{array}$ & $\begin{array}{c}\text { Unit } \\
\text { Under } \\
\text { Test ( }{ }^{\circ} \mathrm{C} \\
\text { ) } \\
\end{array}$ \\
\hline 0.7095 & 0 & 10.8627 & 10 \\
\hline 0.7099 & 0 & 10.8625 & 10 \\
\hline 0.7103 & 0 & 10.8632 & 10 \\
\hline 0.7102 & 0 & 10.8629 & 10 \\
\hline 0.7099 & 0 & 10.8625 & 10 \\
\hline 0.7095 & 0 & 10.8627 & 10 \\
\hline 0.7098 & 0 & 10.8629 & 10 \\
\hline 0.7098 & 0 & 10.8628 & 10 \\
\hline 0.7103 & 0 & 10.8633 & $10, .0$ \\
\hline 0.7096 & 0 & 10.8631 & 10 \\
\hline
\end{tabular}

Table 2. Calibration Result of Digital Thermometer for set point $15^{\circ} \mathrm{C}$ and $20^{\circ} \mathrm{C}$

\begin{tabular}{|c|c|c|c|}
\hline Set Point & $15.0^{\circ} \mathrm{C}$ & Set Point : & $20.0^{\circ} \mathrm{C}$ \\
\hline Standard & & Standard & $\begin{array}{l}\text { Unit } \\
\text { Under }\end{array}$ \\
\hline$\left({ }^{\circ} \mathrm{C}\right)$ & Unit Under Test $\left({ }^{\circ} \mathrm{C}\right)$ & $\left({ }^{\circ} \mathrm{C}\right)$ & $\begin{array}{c}\text { Test ( }{ }^{\circ} \mathrm{C} \\
\end{array}$ \\
\hline 15.7936 & 15 & 20.6989 & 20,0 \\
\hline 15.7939 & 15 & 20.6988 & 20 \\
\hline 15.7936 & 15 & 20.6985 & 20 \\
\hline 15.7938 & 15 & 20.6986 & 20 \\
\hline 15.7941 & 15 & 20.6988 & 20 \\
\hline 15.7944 & 15 & 20.6991 & 20 \\
\hline 15.7942 & 15 & 20.6989 & 20 \\
\hline 15.7943 & 15 & 20.6993 & 20 \\
\hline 15.7941 & 15 & 20.6988 & 20 \\
\hline 15.7943 & 15 & 20.699 & 20 \\
\hline
\end{tabular}

Table 3. Calibration Result of Digital Thermometer for set point $25^{\circ} \mathrm{C}$ and $30{ }^{\circ} \mathrm{C}$

\begin{tabular}{|c|c|c|c|}
\hline Set Point & $25.0^{\circ} \mathrm{C}$ & $\begin{array}{c}\text { Set } \\
\text { Point : }\end{array}$ & $\begin{array}{c}30.0 \\
{ }^{0} \mathrm{C} \\
\end{array}$ \\
\hline $\begin{array}{l}\text { Standard } \\
\left({ }^{\circ} \mathrm{C}\right) \\
\end{array}$ & $\begin{array}{c}\text { Unit Under Test ( } \\
{ }^{\circ} \mathrm{C} \text { ) }\end{array}$ & $\begin{array}{l}\text { Standard } \\
\left({ }^{\circ} \mathrm{C}\right) \\
\end{array}$ & $\begin{array}{c}\text { Unit } \\
\text { Under } \\
\text { Test ( } \\
{ }^{\circ} \mathrm{C} \text { ) } \\
\end{array}$ \\
\hline 25.6485 & 25 & 30.6238 & 30 \\
\hline 25.6484 & 25 & 30.6237 & 30 \\
\hline 25.6491 & 25 & 30.6238 & 30 \\
\hline 25.6487 & 25 & 30.6242 & 30 \\
\hline 25.6488 & 25 & 30.6246 & 30 \\
\hline 25.6494 & 25 & 30.6243 & 30 \\
\hline 25.6492 & 25 & 30.6244 & 30 \\
\hline 25.6488 & 25 & 30.6239 & 30 \\
\hline 25.6487 & 25 & 30.6245 & 30 \\
\hline 25.649 & 25 & 30.6241 & 30 \\
\hline
\end{tabular}

Table 4. Calibration Result of Digital Thermometer for set point $40^{\circ} \mathrm{C}$ and $50{ }^{\circ} \mathrm{C}$

\begin{tabular}{|c|c|c|c|}
\hline Set Point : & $40.0^{\circ} \mathrm{C}$ & $\begin{array}{c}\text { Set } \\
\text { Point : }\end{array}$ & $\begin{array}{c}50.0 \\
{ }^{0} \mathrm{C}\end{array}$ \\
\hline $\begin{array}{c}\text { Standard } \\
\left({ }^{\circ} \mathrm{C}\right)\end{array}$ & $\begin{array}{l}\text { Unit Under Test ( } \\
\left.{ }^{\circ} \mathrm{C}\right)\end{array}$ & $\begin{array}{c}\text { Standard } \\
\left({ }^{\circ} \mathrm{C}\right)\end{array}$ & $\begin{array}{c}\text { Unit } \\
\text { Under } \\
\text { Test ( } \\
\left.{ }^{\circ} \mathrm{C}\right)\end{array}$ \\
\hline 40.8398 & 40 & 51.0562 & 50 \\
\hline 40.8402 & 40 & 51.0559 & 50 \\
\hline 40.8405 & 40 & 51.0562 & 50 \\
\hline 40.8402 & 40 & 51.0567 & 50 \\
\hline 40.8398 & 40 & 51.0564 & 50 \\
\hline 40.8397 & 40 & 51.056 & 50 \\
\hline 40.8395 & 40 & 51.0558 & 50 \\
\hline 40.8397 & 40 & 51.0559 & 50 \\
\hline 40.8399 & 40 & 51.0564 & 50 \\
\hline 40.8405 & 40 & 51.0565 & 50 \\
\hline
\end{tabular}

Table 5. Calibration Result of Digital Thermometer for set point $70^{\circ} \mathrm{C}$ and $100{ }^{\circ} \mathrm{C}$

\begin{tabular}{|c|c|c|c|}
\hline Set Point : & $70.0^{\circ} \mathrm{C}$ & $\begin{array}{c}\text { Set Point } \\
:\end{array}$ & $\begin{array}{c}100.0 \\
{ }^{0} \mathrm{C}\end{array}$ \\
\hline $\begin{array}{l}\text { Standard } \\
\left({ }^{\circ} \mathrm{C}\right)\end{array}$ & $\begin{array}{l}\text { Unit Under Test ( } \\
{ }^{\circ} \mathrm{C} \text { ) }\end{array}$ & $\begin{array}{l}\text { Standard } \\
\left({ }^{\circ} \mathrm{C}\right)\end{array}$ & $\begin{array}{l}\text { Unit } \\
\text { Under } \\
\text { Test ( } \\
\left.{ }^{\circ} \mathrm{C}\right)\end{array}$ \\
\hline 71.1757 & 70 & 101.4711 & 100 \\
\hline 71.1757 & 70 & 101.4714 & 100 \\
\hline 71.1756 & 70 & 101.4718 & 100 \\
\hline 71.1752 & 70 & 101.4713 & 100 \\
\hline 71.1755 & 70 & 101.4714 & 100 \\
\hline 71.1756 & 70 & 101.4715 & 100 \\
\hline 71.1757 & 70 & 101.4718 & 100 \\
\hline 71.1761 & 70 & 101.4711 & 100 \\
\hline 71.1759 & 70 & 101.4713 & 100 \\
\hline 71.1758 & 70 & 101.4714 & 100 \\
\hline
\end{tabular}

Table 6. Calibration Result of Digital Thermometer for set point $120^{\circ} \mathrm{C}$ and $160{ }^{\circ} \mathrm{C}$

\begin{tabular}{|c|c|c|c|}
\hline \multicolumn{2}{|c|}{$\begin{array}{c}120.0{ }^{\circ} \mathrm{C} \\
\text { Set Point : }\end{array}$} & $\begin{array}{c}\text { Set Point } \\
:\end{array}$ & $\begin{array}{c}160.0 \\
{ }^{\circ} \mathrm{C}\end{array}$ \\
\hline Standard $\mathrm{C})$ & $\begin{array}{c}\text { Standard } \\
\text { Under Test }(\end{array}$ & $\begin{array}{c}\text { Unit } \\
\text { Under } \\
\left.{ }^{\circ} \mathrm{C}\right)\end{array}$ & $\begin{array}{c}\text { Test }( \\
\left.{ }^{\circ} \mathrm{C}\right)\end{array}$ \\
\hline 121.6605 & 120 & 162.9064 & 160 \\
\hline 121.6608 & 120 & 162.9065 & 160 \\
\hline 121.6603 & 120 & 162.9064 & 160 \\
\hline 121.6611 & 120 & 162.9071 & 160 \\
\hline 121.6615 & 120 & 162.9074 & 160 \\
\hline 121.6612 & 120 & 162.9076 & 160 \\
\hline 121.6615 & 120 & 162.9075 & 160 \\
\hline 121.6607 & 120 & 162.9067 & 160 \\
\hline 121.6612 & 120 & 162.9069 & 160 \\
\hline 121.661 & 120 & 162.9066 & 160 \\
\hline
\end{tabular}

Published By:

Blue Eyes Intelligence Engineering \& Sciences Publication

(C) Copyright: All rights reserved. 


\section{Calibration of Digital Thermometer using Sensor and Indicator Method}

The method used for calibration of digital thermometer is the working method of sensor plus indicator which is sultry to the quality document MK-12.01 with the title calibration method - Sensor Plus indicator referring to JIS document Z8710:1993, Temperature Measurement - General Requirement and Guide to The Expression of Uncertainty in Measurement, ISO/IEC Guide 98-3:2008 (E) [10, 11]. The standard used is the sensor PT 100 [3] and indicator with the brand Omega (PT100) and Additel (indicator). Calibration is done in environmental conditions $25 \pm 3{ }^{\circ} \mathrm{C}$ for room temperature and $55 \pm 10 \% \mathrm{RH}$ for room humidity. The Media used in this calibration is SIKA Liquid Bath with a temperature range-30 to $165^{\circ} \mathrm{C}$ which is filled with silicon oil.The work was done according to the quality procedures that have been set on the working method, then the calibration worksheet, which contains the raw data was checked. The reporting process is done by calculating the data in the existing document, which is known as MOD or Master of Data. The MOD contains the calibration calculations that are made according to the methods and references that have been established in the laboratory, then verified by the authorized officers and used for the purposes of calculation of calibration results.Based on the results of calibration calculation on Data of Master, obtained in the Table 7.

Table 7. Calibration Result

\begin{tabular}{|c|c|c|c|c|}
\hline $\begin{array}{c}\text { Standard } \\
\left({ }^{0} \mathrm{C}\right)\end{array}$ & $\begin{array}{c}\text { Unit } \\
\text { Under } \\
\text { Test }\left({ }^{0} \mathrm{C}\right)\end{array}$ & $\begin{array}{c}\text { Correction } \\
\left({ }^{0} \mathrm{C}\right)\end{array}$ & $\begin{array}{c}\text { Uncertainty } \\
\left({ }^{0} \mathrm{C}\right)\end{array}$ & $\begin{array}{c}\text { Coverage } \\
\text { Factor }(\mathrm{k})\end{array}$ \\
\hline 0.27 & 0 & 0.27 & 0.32 & 2 \\
\hline 10.4 & 10 & 0.4 & 32 & 2 \\
\hline 15.32 & 15 & 0.32 & 0.32 & 20 \\
\hline 25.16 & 25 & 0.16 & 0.32 & 2 \\
\hline 30.12 & 30 & 0.12 & 0.32 & 2 \\
\hline 40.32 & 40 & 0.32 & 0.32 & 2 \\
\hline 50.52 & 50 & 0.52 & 0.32 & 2 \\
\hline 70.6 & 70 & 0.6 & 0.32 & 2 \\
\hline 100.83 & 100 & 0.83 & 0.32 & 2 \\
\hline 120.97 & 120 & 0.97 & 0.32 & 2 \\
\hline 162.13 & 160 & 2.13 & 0.32 & 2 \\
\hline
\end{tabular}

\section{CONCLUSION}

Calibration of the digital thermometer was carried out at 12 set points, namely $0{ }^{0} \mathrm{C}, 10^{\circ} \mathrm{C}, 15^{\circ} \mathrm{C}, 20{ }^{\circ} \mathrm{C}, 25{ }^{\circ} \mathrm{C}, 30{ }^{\circ} \mathrm{C}$, $40{ }^{\circ} \mathrm{C}, 50{ }^{\circ} \mathrm{C}, 70{ }^{\circ} \mathrm{C}, 100{ }^{\circ} \mathrm{C}, 120^{\circ} \mathrm{C}$, and $160{ }^{\circ} \mathrm{C}$. The average correction of the reading is $0.61{ }^{\circ} \mathrm{C}$ and the uncertainty as $0.32{ }^{\circ} \mathrm{C}$ with $\mathrm{K}$ factor as 2.0 at $95 \%$ confidence level.

\section{ACKNOWLEDGMENT}

Thank you for Lembaga Penelitian dan Pengabdian kepada Masyarakat (LPPM) Universitas Nasional and my collegues in Faculty of Engineering and Science, Universitas Nasional.

2. Colón-Rodríguez, S., et al., Rapid and accurate automatic temperature calibration of disposable screen-printed heated gold electrodes. Journal of Electroanalytical Chemistry, 2019. 851: p. 113414.

3. Paralı, L., F. Durmaz, and O. Aydın, Calibration of a Platinum Resistance Thermometer (Pt-100) and Its Measurement Uncertainty Analysis. Celal Bayar Üniversitesi Fen Bilimleri Dergisi, 2018. 14(1): p. 41-49.

4. Chang, H., Inventing temperature: Measurement and scientific progress. 2004: Oxford University Press.

5. Gorin, G., Correlating Celsius and Fahrenheit temperatures by the" unit calculus". Journal of Chemical Education, 1980. 57(5): p. 350.

6. Liu, H., W. Sun, and S. Xu, An extremely simple thermocouple made of a single layer of metal. Advanced Materials, 2012. 24(24): p. 3275-3279.

7. Hidayanti F., Ramadhani U. F., Gunadi S. Design of Portable Conditioning Chamber with Peltier Element for Transfusion Blood Temperature. International Journal of Engineering and Advanced Technology. 9(3): p. 812-816.

8. Hidayanti, F., Wati E. K., Miftahudin, M. F. Design of Energy Harvesters on Motorcycle Exhaust using Thermoelectric Generator for Power Supply Electronic Device. International Journal of Renewable Energy Research. 10 (1):p. 251-259.

9. Hidayanti F., Wati E. K., Anwar R. Implementation of Peltier Tiles for Heating Jacket. International Journal of Management and Humanities. 4(7):p. 49-51.

10. JIS Z 8710-93: Temperature Measurement - General Requirement, JIS. Japan. 1993.

11. ISO Guide 98-3: Uncertainty of Measurement - Part 3: Guide to the expression of uncertainty in measurement, ISO. Switzerland. 2008.

\section{AUTHORS PROFILE}

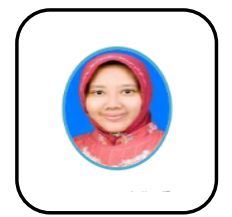

Indonesia.

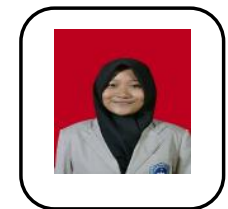

Fitria Hidayanti, Ph.D. candidate at Faculty of Engineering, University of Indonesia. She obtained her bachelor degree at Bandung Institute of Technology, Indonesia and master degree at University of Indonesia. Currently. She is an Assistant Professor at Engineering Physics Department, Universitas Nasional, Jakarta,

Ukhti Fathimah Ramadhani, She obtained Bachelor Degree at Engineering Physics Department, Universitas Nasional, Jakarta, Indonesia.

\section{REFERENCES}

1. Abdalla, M.E., S. Pannir, and E. Khalid, Temperature Measurement And Calibration Setup (TH1). 2018. 